\title{
Synthesis, Topoisomerase I and II Inhibitory Activities, and Cytotoxicity of 4,6-Diaryl-2,4'-bipyridine Derivatives
}

\author{
Radha Karki, Pritam Thapa, Youngjoo Kwon, ${ }^{\dagger, *}$ and Eung-Seok Lee* \\ College of Pharmacy, Yeungnam University, Gyeongsan 712-749, Korea. *E-mail: eslee@yu.ac.kr \\ ${ }^{\dagger}$ College of Pharmacy, Pharmacy \& Division of Life \& Pharmaceutical Sciences, Ewha Womans University, \\ Seoul 120-750, Korea.*E-mail: ykwon@ewha.ac.kr \\ Received February 16, 2010, Accepted March 29, 2010
}

Key Words: 4,6-Diaryl-2,4'-bipyridine, Topoisomerase I and II inhibitors, Cytotoxicity, Antitumor agents

Over the past few years, there has been considerable interest in DNA topoisomerases, as they were shown to be the cellular targets for several anticancer drugs. ${ }^{1}$ DNA topoisomerases are ubiquitous enzymes that relieve the torsional stress in the DNA helix that is generated as a result of replication, transcription, and other nuclear processes. ${ }^{2}$ They are classified as topoisomerase I (topo I) and topoisomerase II (topo II). The topo I transiently break DNA strands one at a time, and the topo II cut a pair of strands in a DNA double helix. ${ }^{3}$ Topoisomerases are essential enzymes, which once inhibited, induce great damage to DNA of tumor cells. ${ }^{4}$

Terpyridine molecule can act as tridentate ligand and form stable complexes by chelating a broad variety of transition metal ions. The numerous reports on DNA binding property and antitumor activity of terpyridine complexes have attracted multiple researchers. ${ }^{5} \alpha$-Terpyridines are the bioisosteres of $\alpha$-terthiophene which possess protein kinase $\mathrm{C}$ (PKC) inhibitory activity. ${ }^{6}$ Our research group reported that terpyridine derivatives showed a strong cytotoxicity against several human cancer cell lines, and considerable topo I and II inhibitory activity. ${ }^{7} 4$ '-Pyridine at 2-position of central pyridine was found to be important to display topo I and topo II inhibitory activities as well as cytotoxicity. ${ }^{7 \mathrm{~d}}$ In addition, it was observed that substitution with $\mathrm{CH}_{3}$ or $\mathrm{Cl}$ enhanced topo I or topo II inhibitory activity. ${ }^{7 \mathrm{fg}, \mathrm{h}}$ In this study, we designed and synthesized fifteen compounds substituted by 4'-pyridine at 2 position and various 5 - and 6-membered heteroaromatics containing $\mathrm{CH}_{3}$ or $\mathrm{Cl}$ group at 4 and 6 positions of central pyridine, and evaluated for topo I and II inhibitory activity, and cytotoxicity against several human cancer cell lines (Figure 1).

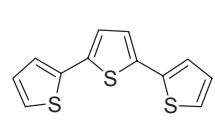

$\alpha$-terthiophene

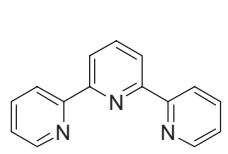

$\alpha$-terpyridine

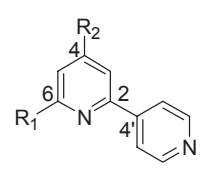

4,6-diaryl-2,4'-bipyridine
Figure 1. Structures of $\alpha$-terthiophene, $\alpha$-terpyridine and 4,6-diaryl2,4'-bipyridine.

\section{Experimental Section}

Compounds used as starting materials and reagents were obtained from Aldrich Chemical Co., Junsei or other chemical companies, and utilized without further purification. HPLC grade acetonitrile $(\mathrm{ACN})$ and methanol were purchased from Burdick and Jackson, USA. Thin-layer chromatography (TLC) and column chromatography (CC) were performed with Kieselgel $60 \mathrm{~F}_{254}$ (Merck) and silica gel (Kieselgel 60, 230 - 400 mesh, Merck) respectively. Since all the compounds prepared contain aromatic ring, they were visualized and detected on TLC plates with UV light (short wave, long wave or both). NMR spectra were recorded on a Bruker AMX $250(250 \mathrm{MHz}, \mathrm{FT})$ for ${ }^{1} \mathrm{H}$ NMR and $62.5 \mathrm{MHz}$ for ${ }^{13} \mathrm{C} \mathrm{NMR}$, and chemical shifts were calibrated according to TMS. Chemical shifts $(\delta)$ were recorded in ppm and coupling constants $(J)$ in hertz $(\mathrm{Hz})$. Melting points were determined in open capillary tubes on electrothermal 1A 9100 digital melting point apparatus and were uncorrected.

HPLC and ESI LC/MS analyses were performed using the same methods which were previously reported. ${ }^{7 \mathrm{i}}$

General method for the preparation of 3. Aryl ketone was added to the solution of $85 \% \mathrm{KOH}(1.2 \mathrm{eq})$ in $\mathrm{MeOH} / \mathrm{H}_{2} \mathrm{O}$ $(5: 1)$ at $0{ }^{\circ} \mathrm{C}$. After complete dissolution, aryl aldehyde was added slowly. The mixture was then stirred for $3 \mathrm{~h}$ at $0^{\circ} \mathrm{C}$. Precipitate was formed in most of the cases which was then filtered, washed with cold $\mathrm{MeOH}$, and dried to yield $31.2-98.3 \%$ as a solid. In those reactions where no precipitate occurred, the reaction mixtures were extracted with ethyl acetate and washed with water. It was then further purified by either recrystallization or column chromatography.

General method for the preparation of 4. A mixture of 4-acetyl pyridine, iodine $(1.2 \mathrm{eq})$ and pyridine was refluxed at $140{ }^{\circ} \mathrm{C}$ for $3 \mathrm{~h}$. Precipitate occurred during reaction which was cooled to room temperature. Then it was filtered and washed with cold pyridine to afford $\mathbf{4}$ in quantitative yield.

General method for the preparation of 5. A mixture of propenone intermediate $\mathbf{3}\left(\mathbf{R}_{\mathbf{1}}=\mathbf{a}-\mathbf{c}, \mathbf{e}, \mathbf{f}, \mathbf{R}_{\mathbf{2}}=\mathbf{a}-\mathbf{e}, \mathbf{g}-\mathbf{i}\right)$, pyridinium iodide salt $\mathbf{4}$ and anhydrous ammonium acetate in glacial acetic acid were heated at $80-100{ }^{\circ} \mathrm{C}$ for $12-24 \mathrm{~h}$. The reaction mixture was then extracted with ethyl acetate, washed with water and brine solution. The organic layer was dried with magnesium sulfate and filtered. The filtrate was evaporated at reduced pressure, which was then purified by silica gel column chromatography with the gradient elution of ethyl acetate $/ n$-hexane to afford solid compounds $\mathbf{5}\left(\mathbf{R}_{\mathbf{1}}=\mathbf{a}-\mathbf{c}, \mathbf{e}, \mathbf{f}, \mathbf{R}_{\mathbf{2}}=\mathbf{a}-\mathbf{e}, \mathbf{g - i}\right)$ in $21.1 \%-46.4 \%$ yield.

Synthesis of 4-(furan-2-yl)-6-(3-methyl-thiophen-2-yl)-2,4'bipyridine (15): The procedure described above was employed 
with $\mathbf{3}\left(\mathbf{R}_{\mathbf{1}}=\mathbf{e}, \mathbf{R}_{\mathbf{2}}=\mathbf{c}\right)$, anhydrous ammonium acetate, $\mathbf{4}$, and glacial AcOH to yield light yellow solid compound (26.5\%). $R_{f}$ (ethyl acetate $/ n$-hexane $\left.1: 1, \mathrm{v} / \mathrm{v}\right): 0.34 ; \%$ purity by HPLC: $100 \%$; mp 149.0 - $149.6{ }^{\circ} \mathrm{C}$, LC MS/MS: retention time: 11.52 min; $[\mathrm{MH}]^{+}:$319.30. ${ }^{1} \mathrm{H}$ NMR $\left(250 \mathrm{MHz}, \mathrm{CDCl}_{3}\right) \delta 8.72(\mathrm{dd}$, $J=4.6,1.6 \mathrm{~Hz}, 1 \mathrm{H}, 2$-pyridine H-2', H-6'), 8.01 (dd, $J=4.6$, 1.6 Hz, 1H, 2-pyridine H-3', H-5'), 7.87 (s, 1H, pyridine $\mathrm{H}-3$ ), 7.79 (s, $1 \mathrm{H}$, pyridine $\mathrm{H}-5), 7.58$ (dd, $J=1.6,0.5 \mathrm{~Hz}, 1 \mathrm{H}, 4$-furan H-5), 7.29 (d, J=5.0 Hz, 1H, 6-thiophene H-5), 6.96 (m, 2H, 4-furan H-3, 6-thiophene H-4), 6.56 (dd, $J=3.4,1.7 \mathrm{~Hz}, 1 \mathrm{H}$, 4-furan $\mathrm{H}-4), 2.62$ (s, 3H, 6-thiophene $\left.3-\mathrm{CH}_{3}\right) .{ }^{13} \mathrm{C}$ NMR $(62.5$ $\left.\mathrm{MHz}, \mathrm{CDCl}_{3}\right) \delta 154.38,154.20,151.18,150.36,146.06,143.98$, $139.12,137.48,136.37,132.35,125.82,121.02,155.15,112.22$, 109.05, 16.58.

Synthesis of 4-(5-methylfuran-2-yl)-6-(thiophen-2-yl)-2,4'bipyridine (16): The procedure described above was employed with $\mathbf{3}\left(\mathbf{R}_{\mathbf{1}}=\mathbf{a}, \mathbf{R}_{\mathbf{2}}=\mathbf{g}\right)$, anhydrous ammonium acetate, $\mathbf{4}$, and glacial AcOH to yield light yellow crystal (27.3\%). $R_{f}$ (ethyl acetate $/ n$-hexane $1: 1, \mathrm{v} / \mathrm{v}$ ): $0.15 ; \%$ purity by HPLC: $100 \%$; mp 177.6 - $1178.3^{\circ} \mathrm{C}, \mathrm{LC}$ MS/MS: retention time: $12.04 \mathrm{~min}$; $[\mathrm{MH}]^{+}:$319.26. ${ }^{1} \mathrm{H}$ NMR $\left(250 \mathrm{MHz}, \mathrm{CDCl}_{3}\right) \delta 8.74$ (dd, $J=4.6$, $1.5 \mathrm{~Hz}, 2 \mathrm{H}, 2$-pyridine H-2', H-6'), 8.03 (dd, $J=4.6,1.5 \mathrm{~Hz}$, 2H, 2-pyridine H-3', H-5'), 7.81 (s, 2H, pyridine H-3, H-5), 7.72 (dd, $J=3.6,0.8 \mathrm{~Hz}, 1 \mathrm{H}, 6$-thiophene $\mathrm{H}-3$ ), 7.43 (dd, $J=5.0$, $0.8 \mathrm{~Hz}, 1 \mathrm{H}, 6$-thiophene H-5), 7.15 (dd, $J=5.0,3.7 \mathrm{~Hz}, 1 \mathrm{H}$, 6-thiophene H-4), 6.88 (d, $J=3.3 \mathrm{~Hz}, 1 \mathrm{H}, 4$-furan $\mathrm{H}-3), 6.16$ (dd, $J=3.2,0.7 \mathrm{~Hz}, 1 \mathrm{H}, 4$-furan $\mathrm{H}-4), 2.42$ (s, 3H, 4-furan 5- $\left.\mathrm{CH}_{3}\right) .{ }^{13} \mathrm{CNMR}\left(62.5 \mathrm{MHz}, \mathrm{CDCl}_{3}\right) \delta 154.47,154.35,153.08$, $150.38,149.41,146.02,144.84,139.48,128.01,124.96,121.05$, $112.49,112.08,110.36,108.58,13.91$.

Synthesis of 4-(5-chlorofuran-2-yl)-6-(thiophen-2-yl)-2,4'bipyridine (17): The procedure described above was employed with $\mathbf{3}\left(\mathbf{R}_{\mathbf{1}}=\mathbf{a}, \mathbf{R}_{\mathbf{2}}=\mathbf{h}\right)$, anhydrous ammonium acetate, $\mathbf{4}$, and glacial AcOH to yield brown solid (24.9\%). $R_{f}$ (ethyl acetate/ $n$-hexane $1: 1, \mathrm{v} / \mathrm{v}): 0.36$; $\%$ purity by HPLC: $100 \%$; mp 196.3 197.0 ${ }^{\circ} \mathrm{C}, \mathrm{LC}$ MS/MS: retention time: $12.41 \mathrm{~min} ;[\mathrm{MH}]^{+}: 339.21$. ${ }^{1} \mathrm{H}$ NMR $\left(250 \mathrm{MHz}, \mathrm{CDCl}_{3}\right) \delta 8.75(\mathrm{dd}, J=4.5,1.6 \mathrm{~Hz}, 2 \mathrm{H}$, 2-pyridine H-2', H-6'), 8.01 (dd, $J=4.5,1.6 \mathrm{~Hz}, 2 \mathrm{H}, 2$-pyridine H-3', H-5'), 7.79 (s, 2H, pyridine H-3, H-5), 7.72 (dd, $J=3.7$, $1.0 \mathrm{~Hz}, 1 \mathrm{H}, 6$-thiophene H-3), 7.45 (dd, $J=5.0,1.0 \mathrm{~Hz}, 1 \mathrm{H}$, 6-thiophene H-5), 7.15 (dd, $J=5.0,3.7 \mathrm{~Hz}, 1 \mathrm{H}, 6$-thiophene H-4), 6.96 (d, $J=3.5 \mathrm{~Hz}, 1 \mathrm{H}$, 4-furan H-3), 6.36 (d, $J=3.5 \mathrm{~Hz}$, $1 \mathrm{H}, 4$-furan $\mathrm{H}-4) .{ }^{13} \mathrm{C} \mathrm{NMR}\left(62.5 \mathrm{MHz}, \mathrm{CDCl}_{3}\right) \delta 154.63$, $153.32,150.52,150.44,145.68,144.46,138.52,138.28,128.33$, $128.10,125.24,121.02,112.34,112.03,111.10,109.01$.

Synthesis of 6-(5-chlorothiophen-2-yl)-4-(furan-2-yl)-2,4'bipyridine (18): The procedure described above was employed with $\mathbf{3}\left(\mathbf{R}_{\mathbf{1}}=\mathbf{f}, \mathbf{R}_{\mathbf{2}}=\mathbf{c}\right)$, anhydrous ammonium acetate, $\mathbf{4}$, and glacial AcOH to yield greenish solid (23.2\%). $R_{f}$ (ethyl acetate/ $n$-hexane $2: 1, \mathrm{v} / \mathrm{v}): 0.40 ; \%$ purity by HPLC: $97.64 \%$; mp 196.6 - $197.2^{\circ} \mathrm{C}, \mathrm{LC} \mathrm{MS} / \mathrm{MS}$ : retention time: $12.88 \mathrm{~min}$; $[\mathrm{MH}]^{+}$: 339.25. ${ }^{1} \mathrm{H}$ NMR $\left(250 \mathrm{MHz}, \mathrm{CDCl}_{3}\right) \delta 8.74(\mathrm{dd}, J=4.5,1.6$ Hz, 2H, 2-pyridine H-2', H-6'), 7.98 (dd, $J=4.5,1.6 \mathrm{~Hz}, 2 \mathrm{H}$, 2-pyridine $\mathrm{H}^{-3}$ ', H-5'), 7.86 (d, $J=1.2 \mathrm{~Hz}, 1 \mathrm{H}$, pyridine $\mathrm{H}-3$ ), $7.78(\mathrm{~d}, J=1.2 \mathrm{~Hz}, 1 \mathrm{H}$, pyridine $\mathrm{H}-5), 7.59$ (d, $J=1.6 \mathrm{~Hz}, 1 \mathrm{H}$, 4-furan H-5), 7.45 (d, $J=3.9 \mathrm{~Hz}, 1 \mathrm{H}, 6$-thiophene H-3), 6.98 (d, $J=3.4 \mathrm{~Hz}, 1 \mathrm{H}, 4$-furan H-3), 6.95 (d, $J=3.9 \mathrm{~Hz}, 1 \mathrm{H}, 6$-thiophene $\mathrm{H}-4), 6.57$ (dd, $J=3.4,1.8 \mathrm{~Hz}, 1 \mathrm{H}, 4$-furan $\mathrm{H}-4) .{ }^{13} \mathrm{C}$
NMR $\left(62.5 \mathrm{MHz}, \mathrm{CDCl}_{3}\right) \delta 154.56,152.45,150.98,150.47$, $145.58,144.13,143.36,139.43,133.15,127.22$, 124.00, 120.95, 113.12, 112.32, 111.81, 109.32.

Pharmacology. The topoisomerase I inhibitory activity was carried out as following. ${ }^{8}$ The prepared compounds were dissolved in DMSO at $20 \mathrm{mM}$ as stock solution. The activity of DNA topoisomerase I was determined by assessing the relaxation of supercoiled DNA pBR322. The mixture of $100 \mathrm{ng}$ of plasmid pBR322 DNA and 0.2 units of calf thymus DNA topoisomerase I (Fermentas, USA) was incubated without and with the prepared compounds at $37{ }^{\circ} \mathrm{C}$ for 30 minutes in the relaxation buffer (35 mM Tris- $\mathrm{HCl}$ (pH 8.0), $72 \mathrm{mM} \mathrm{KCl,} 5 \mathrm{mM} \mathrm{MgCl}_{2}$, $5 \mathrm{mM}$ dithiothreitol, $2 \mathrm{mM}$ spermidine, $0.01 \%$ bovine serum albumin). The reaction in the final volume of $10 \mu \mathrm{L}$ was terminated by adding $2.5 \mu \mathrm{L}$ of the stop solution containing $10 \%$ SDS, $0.2 \%$ bromophenol blue, $0.2 \%$ xylene cyanol and $30 \%$ glycerol. DNA samples were then electrophoresed on a $1 \%$ agarose gel at $15 \mathrm{~V}$ for $7 \mathrm{~h}$ with a running buffer of TAE. Gels were stained for $30 \mathrm{~min}$ in an aqueous solution of ethidium bromide $(0.5 \mu \mathrm{g} / \mathrm{mL})$. DNA bands were visualized by transillumination with UV light and were quantitated using AlphaImager ${ }^{\mathrm{TM}}$ (Alpha Innotech Corporation).

DNA topoisomerase II inhibitory activity of compounds were measured as follows. ${ }^{9}$ The mixture of $200 \mathrm{ng}$ of supercoiled pBR322 plasmid DNA and 2 units of human DNA topoisomerase II $\alpha$ (Amersham, USA) was incubated without and with the prepared compounds in the assay buffer $(10 \mathrm{mM}$ Tris- $\mathrm{HCl}$ (pH 7.9) containing $50 \mathrm{mM} \mathrm{NaCl}, 5 \mathrm{mM} \mathrm{MgCl}, 1 \mathrm{mM}$ EDTA, $1 \mathrm{mM}$ ATP, and $15 \mu \mathrm{g} / \mathrm{mL}$ bovine serum albumin) for $30 \mathrm{~min}$ at $30{ }^{\circ} \mathrm{C}$. The reaction in a final volume of $20 \mu \mathrm{L}$ was terminated by the addition of $3 \mu \mathrm{L}$ of $7 \mathrm{mM}$ EDTA. Reaction products were analyzed on $1 \%$ agarose gel at $25 \mathrm{~V}$ for $4 \mathrm{~h}$ with a running buffer of TAE. Gels were stained for $30 \mathrm{~min}$ in an aqueous solution of ethidium bromide $(0.5 \mu \mathrm{g} / \mathrm{mL})$. DNA bands were visualized by transillumination with UV light and supercoiled DNA was quantitated using AlphaImager ${ }^{\mathrm{TM}}$ (Alpha Innotech Corporation).
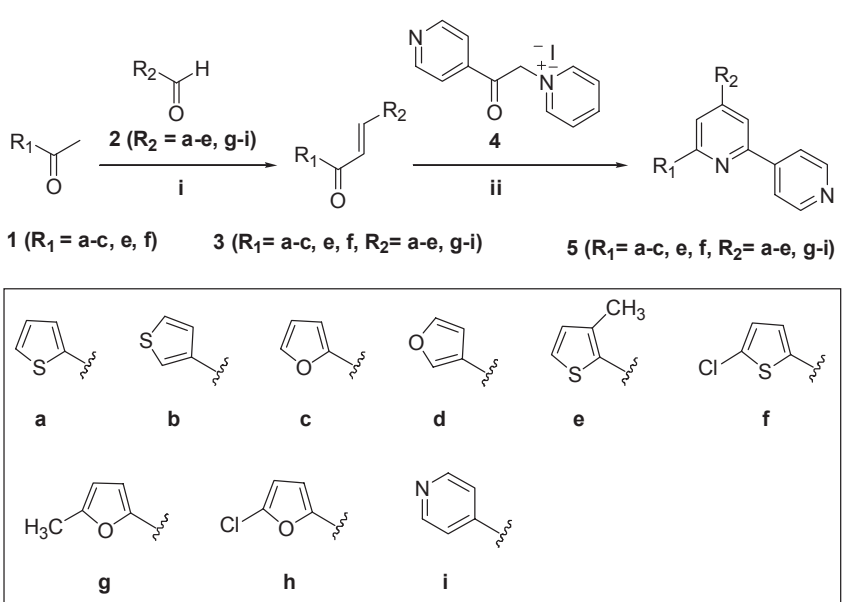

Scheme 1. General synthetic scheme of 4,6-diaryl-2,4'-bipyridine. Reagents and conditions: (i) aryl aldehydes $\mathbf{2}$ (a-e, g-i), (1.0 eq), $\mathrm{KOH}$ (1.2 eq), $\mathrm{MeOH} / \mathrm{H}_{2} \mathrm{O}(5: 1), 0{ }^{\circ} \mathrm{C}, 3 \mathrm{~h}, 31.2$ - 98.3\%; (ii) 3 (R $\mathbf{1}=\mathbf{a - c}$, e, $\left.\mathbf{f}, \mathbf{R}_{2}=\mathbf{a}-\mathbf{e}, \mathbf{g}-\mathbf{i}\right)$ (1.0 eq), 4 (1.0 eq), $\mathrm{NH}_{4} \mathrm{OAc}$ (10.0 eq), $\mathrm{AcOH}, 80-$ $100{ }^{\circ} \mathrm{C}, 12-24$ h, $21.1-46.4 \%$ yield. 
Cancer cells were cultured according to the supplier's instructions. Cells were seeded in 96-well plates at a density of $2 \sim 4 \times 10^{4}$ cells per well and incubated for overnight in $0.1 \mathrm{~mL}$ of media supplied with 10\% Fetal Bovine Serum (Hyclone, USA) in $5 \% \mathrm{CO}_{2}$ incubator at $37{ }^{\circ} \mathrm{C}$. On day 2 , culture medium in each well was exchanged with $0.1 \mathrm{~mL}$ aliquots of medium containing graded concentrations of compounds. On day 4, each well was added with $5 \mu \mathrm{L}$ of the cell counting kit- 8 solution (Dojindo, Japan) then incubated for additional $4 \mathrm{~h}$ under the same condition. The absorbance of each well was determined by an Automatic Elisa Reader System (Bio-Rad 3550) at $450 \mathrm{~nm}$ wavelength. For determination of the $\mathrm{IC}_{50}$ values, the absorbance readings at $450 \mathrm{~nm}$ were fitted to the four-parameter logistic equation. Adriamycin, etoposide, and camptothecin were purchased from Sigma and used as positive controls.

\section{Results and Discussion}

Synthetic chemistry. Synthetic method for the preparation of 4,6-diaryl-2,4'-bipyridine derivatives $\mathbf{6}$ - $\mathbf{2 0}$ are summarized in Scheme 1. Aryl acetyl ketones $\mathbf{1}(\mathbf{a}-\mathbf{c}, \mathbf{e}, \mathbf{f})$ were treated with aryl aldehydes $\mathbf{2}$ (a-e, g-i) in the presence of $\mathrm{KOH}$ in methanol/ water (5:1), to afford propenone intermediates $\mathbf{3}\left(\mathbf{R}_{\mathbf{1}}=\mathbf{a - c}, \mathbf{e}, \mathbf{f}\right.$, $\left.\mathbf{R}_{\mathbf{2}}=\mathbf{a}-\mathbf{e}, \mathbf{g}-\mathbf{i}\right)$ in $31.2-98.3 \%$ yield. Pyridinium iodide salt $\mathbf{4}$ was synthesized in a quantitative yield by the treatment of 4-acetyl pyridine with iodine in pyridine. Using modified Kröhnke synthesis, ${ }^{10}$ final compounds $\mathbf{5}\left(\mathbf{R}_{\mathbf{1}}=\mathbf{a}-\mathbf{c}, \mathbf{e}, \mathbf{f}, \mathbf{R}_{\mathbf{2}}=\mathbf{a}-\mathbf{e}, \mathbf{g}-\mathbf{i}\right)$ were synthesized by the reaction of propenone intermediate 3 with pyridinium iodide salt 4 in the presence of ammonium acetate and acetic acid in $21.1-46.4 \%$ yield. Figure 2 shows structure of prepared compounds.

Topo I and II inhibitory activity of compounds 6-20. The conversion of supercoiled plasmid DNA to relaxed DNA by topo I and II was examined in the presence of prepared 4,6diaryl-2,4'-bipyridine derivatives 6-20. Camptothecin and etoposide, well- known topo I and II inhibitors, respectively, were used as positive controls. All the compounds, except 16, were devoid of topo I inhibitory activity at both $20 \mu \mathrm{M}$ and $100 \mu \mathrm{M}$ concentrations. Compound $\mathbf{1 6}$ had considerable topo I inhibitory activity as shown in Figure 3. The effect of prepared compounds on human DNA topo II $\alpha$ were observed in the relaxation assays using supercoiled pBR322 plasmid DNA in the presence of ATP. The reaction products were analyzed by electrophoretic mobility and developed in ethidium bromide in the presence of UV light. As shown in Figure 4, compounds 13-20 exhibited significant topo II $\alpha$ inhibitory activity. Compounds 6-12 did not show considerable topo II inhibitory activity compared to other compounds. Table 1 indicates the percentage inhibition of topo I and II with compounds 13-20 at concentrations $20 \mu \mathrm{M}$ and $100 \mu \mathrm{M}$.

Cytotoxicity. Compounds 6-14 did not show considerable cytotoxicity but compounds $\mathbf{1 5 - 2 0}$ showed significant cytotoxicity. The $\mathrm{IC}_{50}$ values of 4,6-diaryl-2,4'-bipyridine derivatives 15-20 against those cell lines are shown in Table 1. Most of the compounds showed significant cytotoxicity, generally less than $\mathrm{IC}_{50}$ value of $10 \mu \mathrm{M}$. Compounds 15-18, 20 show the most significant cytotoxicity against $\mathrm{HCT} 15$ with $\mathrm{IC}_{50}$ value of $2-3 \mu \mathrm{M}$. It supports the idea that 4'-pyridine at 2-position of central pyridine with combination of 2-thienyl, 3-thienyl or 2-furyl moieties are crucial in displaying cytotoxicity, especially on HCT15, as reported previously. ${ }^{7 \mathrm{~d}}$

In conclusion, we have designed and synthesized fifteen compounds by efficient synthetic routes and evaluated them for topo I and II inhibitory activity along with cytotoxicity against

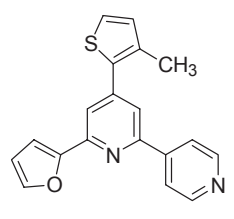<smiles>Cc1ccsc1-c1cc(-c2ccsc2)cc(-c2ccncc2)n1</smiles>

11

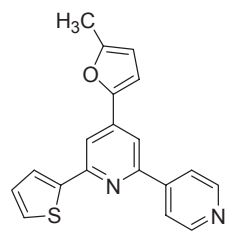

16
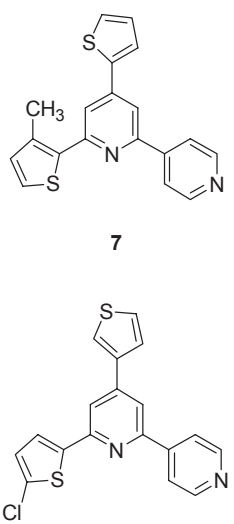

12

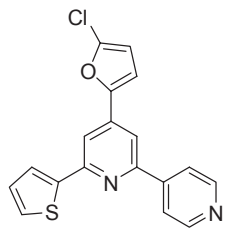

17

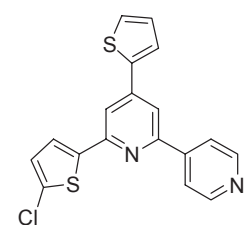

8

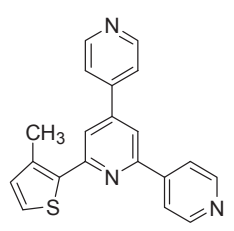

13

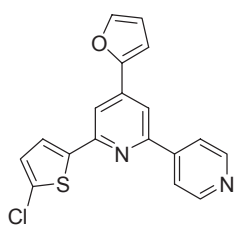

18<smiles>Cc1ccsc1-c1cc(-c2ccncc2)nc(-c2cccs2)c1</smiles><smiles>Clc1ccc(-c2cc(-c3ccncc3)cc(-c3ccncc3)n2)s1</smiles>

14<smiles>Cc1ccsc1-c1cc(-c2ccoc2)cc(-c2ccncc2)n1</smiles>

19

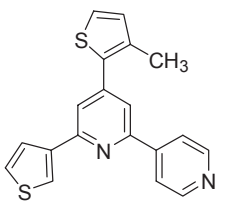

10<smiles>Cc1ccsc1-c1cc(-c2ccco2)cc(-c2ccncc2)n1</smiles>

15

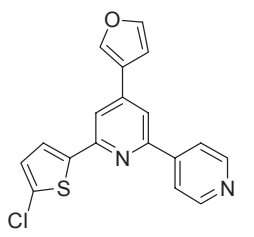

20

Figure 2. Structure of the prepared compounds. 
Table 1. Topoisomerase I and II inhibitory activity and cytotoxicity of the prepared compounds 13-20

\begin{tabular}{|c|c|c|c|c|c|c|c|c|c|}
\hline \multirow{3}{*}{ Compounds } & \multicolumn{4}{|c|}{$\%$ Inhibition } & \multicolumn{5}{|c|}{$\mathrm{IC}_{50}{ }^{a}(\mu \mathrm{M})$} \\
\hline & \multicolumn{2}{|c|}{ Topo II } & \multicolumn{2}{|c|}{ Topo I } & \multirow[t]{2}{*}{ MDA-MB231 } & \multirow[t]{2}{*}{$\mathrm{HeLa}$} & \multirow[t]{2}{*}{ DU145 } & \multirow[t]{2}{*}{ HCT15 } & \multirow[t]{2}{*}{ HL60 } \\
\hline & $100 \mu \mathrm{M}$ & $20 \mu \mathrm{M}$ & $100 \mu \mathrm{M}$ & $20 \mu \mathrm{M}$ & & & & & \\
\hline Etoposide & 61.7 & 40.5 & & & $0.9 \pm 0.06$ & $1.6 \pm 0.14$ & $0.6 \pm 0.04$ & $0.9 \pm 0.11$ & $0.8 \pm 0.01$ \\
\hline Camptothecin & & & 56.2 & 43.9 & $0.3 \pm 0.07$ & $0.2 \pm 0.07$ & $0.2 \pm 0.03$ & $0.5 \pm 0.09$ & $0.1 \pm 0.00$ \\
\hline Adriamycin & & & & & $0.4 \pm 0.07$ & $0.8 \pm 0.07$ & $1.0 \pm 0.22$ & $1.1 \pm 0.08$ & $0.7 \pm 0.01$ \\
\hline 13 & 29.8 & NA & 4.3 & NA & NA & NA & NA & NA & NA \\
\hline 14 & 27.3 & NA & 3.6 & NA & NA & NA & NA & NA & NA \\
\hline 15 & 35.3 & 6.7 & 10.6 & NA & $6.7 \pm 0.81$ & $4.5 \pm 2.09$ & $6.5 \pm 0.61$ & $3.4 \pm 0.16$ & $4.7 \pm 1.18$ \\
\hline 16 & 29.5 & 0.0 & 55.8 & 15.2 & $7.3 \pm 0.74$ & $4.7 \pm 1.00$ & $3.6 \pm 0.57$ & $3.4 \pm 0.33$ & $4.3 \pm 0.64$ \\
\hline 17 & 42.9 & 0.0 & 13.7 & NA & $28.3 \pm 0.77$ & $33.7 \pm 5.91$ & $18.2 \pm 2.04$ & $2.3 \pm 0.08$ & $2.1 \pm 0.09$ \\
\hline 18 & 44.7 & 0.0 & 6.2 & NA & $18.7 \pm 1.80$ & $3.7 \pm 0.15$ & $6.4 \pm 1.56$ & $2.1 \pm 0.08$ & $6.5 \pm 0.24$ \\
\hline 19 & 26.0 & 0.0 & 12.9 & NA & $11.8 \pm 0.74$ & $5.7 \pm 0.21$ & $4.6 \pm 1.65$ & $18.4 \pm 0.09$ & $14.4 \pm 0.33$ \\
\hline 20 & 30.9 & 4.7 & 5.6 & NA & $11.1 \pm 1.26$ & $6.8 \pm 0.25$ & $4.5 \pm 1.22$ & $2.6 \pm 0.53$ & $11.0 \pm 0.14$ \\
\hline
\end{tabular}

${ }^{\bar{a}}$ Each data point represents mean \pm S. D. from three different experiments performed in triplicate. NA: Not applicable. Cell lines used are MDA-MB231, human breast tumor cell line; HeLa, human cervix tumor cell line; DU145, human prostate tumor cell line; HCT15, human colorectal adenocarcinoma cell line; HL60, human myeloid leukemic tumor cell lines.

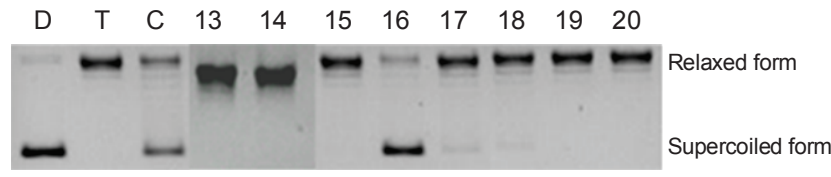

Lane D: pBR322 DNA only

Lane T: pBR322 DNA + Topo I

Lane C: pBR322 DNA + Topo I + Camptothecin $(100 \mu \mathrm{M})$

Lane 1-15: pBR322 DNA + Topo I + Compounds 13-20 (100 $\mu \mathrm{M})$

Figure 3. Calf thymus DNA Topo I inhibitory effect of compounds 13-20.

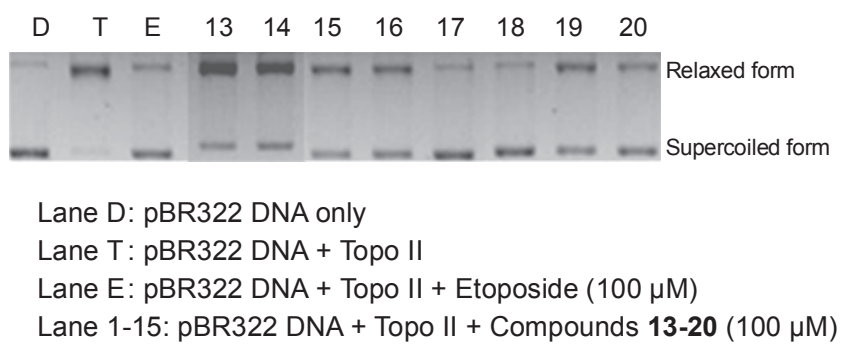

Figure 4. Human DNA Topo II $\alpha$ inhibitory effect of compounds 13-20.

several human cancer cell lines. Although most of the compounds did not display significant topo I inhibitory activity, several compounds (13-20) possessed considerable topo II inhibitory activity and cytotoxicity. A structure-activity relationship study of 4,6-diaryl-2,4'-bipyridine derivatives for topo II inhibitory activity indicates that 6-thienyl-4-furyl moiety along with 4'-pyridine at 2 position is crucial in displaying topo II inhibitory activity, and cytotoxicity. Further research in this skeleton is necessary for the development of potent anticancer agents. This study may provide valuable information to researchers working on the development of antitumor agents.

Acknowledgments. This research was supported by the Yeungnam University research grants in 2008.

\section{References}

1. Topcu, Z. J. Clin. Pharm. Ther. 2001, 26, 405.

2. Staker, B. L.; Feese, M. D.; Cushman, M.; Pommier, Y; Zembower, D.; Stewart, L.; Burgin, A. B. J. Med. Chem. 2005, 48, 2336.

3. Wang, J. C. Nat. Rev. Cancer 2002, 3, 430.

4. Gijn, R. V.; Lendfers, R. R. H.; Schellens, J. H. M.; Bult, A.; Beijnen, J. H. J. Oncol. Pharm. Practice 2000, 3, 92.

5. (a) Schubert, U. S.; Eschbaumer, C. Angew. Chem. Int. Ed. 2002, 41, 2892. (b) Lowe, G.; Droz, A. S.; Vilaivan, T.; Weaver, G. W.; Park, J. J.; Pratt, J. M.; Tweedale, L.; Kelland, L. R. J. Med. Chem. 1999, 42, 3167. (c) Carter, P. J.; Cheng, C. C.; Thorp, H. H. J. Am. Chem. Soc. 1998, 120, 632. (d) McCoubrey, A.; Latham, H. C.; Cook, P. R.; Rodger, A.; Lowe, G. FEBS Lett. 1996, 380, 73.

6. Kim, D. S. H. L.; Ashendel, C. L.; Zhou, Q.; Chang, C. T.; Lee, E. S.; Chang, C. J. Bioorg. Med. Chem. Lett. 1998, 8, 2695.

7. (a) Zhao, L. X.; Kim, T. S.; Ahn, S. H.; Kim, T. H.; Kim, E. K.; Cho, W. J.; Choi, H.; Lee, C. S.; Kim, J. A.; Jeong, T. C.; Chang, C. J.; Lee, E. S. Bioorg. Med. Chem. Lett. 2001, 11, 2659. (b) Zhao, L. X.; Moon, Y. S.; Basnet, A.; Kim, E. K.; Jhang, Y.; Park, J. G.; Jeong, T. C.; Cho, W. J.; Choi, S. U.; Lee, C. O.; Lee, S. Y.; Lee, C. S.; Lee, E. S. Bioorg. Med. Chem. Lett. 2004, 14, 1333. (c) Zhao, L. X.; Sherchan, J.; Park, J. K.; Jhang, Y.; Jeong, B. S.; Jeong, T. C.; Lee, C. S.; Lee, E. S. Arch. Pharm. Res. 2006, 29, 1091. (d) Basnet, A.; Thapa, P.; Karki, R.; Na, Y.; Jhang, Y.; Jeong, B. S.; Jeong, T. C.; Lee, C. S.; Lee, E. S. Bioorg. Med. Chem. 2007, 15, 4351. (e) Thapa, P.; Karki, R.; Basnet, A.; Thapa, U.; Choi, H. Y.; Na, Y.; Jahng, Y., Lee, C. S.; Kwon, Y.; Jeong, B. S.; Lee, E. S. Bull. Korean Chem. Soc. 2008, 29, 1605. (f) Basnet, A.; Thapa, P.; Karki, R.; Choi, H. Y.; Choi, J. H; Yun, M.; Jeong, B. S.; Jahng, Y.; Na, Y.; Cho, W. J.; Kwon, Y.; Lee, C. S.; Lee, E.-S. Bioorg. Med. Chem. Lett . 2010, 20, 42. (g) Thapa, P.; Karki, R.; Thapa, U.; Jahng, Y.; Jung, M. J.; Nam, J. M.; Na, Y.; Kwon, Y.; Lee, E.-S. Bioorg. Med. Chem. 2010, 18, 377. (h) Thapa, P.; Karki, R.; Choi, H. Y.; Choi, J. H.; Yun, M.; Jeong, B. S.; Jung, M. J.; Nam, J. M.; Na, Y.; Cho, W. J.; Kwon, Y.; Lee, E.-S. Bioorg. Med. Chem. 2010, 18, 2245. (i) Karki, R.; Thapa, P.; Kang, M. J.; Jeong, T. C.; Nam, J. M.; Kim, H.-L.; Na, Y.; Cho, W. J.; Kwon, Y.; Lee, E.-S. Bioorg. Med. Chem. 2010, 18, 3066.

8. Fukuda, M.; Nishio, K.; Kanzawa, F.; Ogasawara, H.; Ishida, T.; Arioka, H.; Bonjanowski, K.; Oka, M.; Saijo, N. Cancer Res. 1996, 56,789 .

9. Kang, D. H.; Kim, J. S.; Jung, M. J.; Lee, E. S.; Jhang, Y.; Kwon, Y.; Na, Y. Bioorg. Med. Chem. Lett. 2008, 18, 1520.

10. (a) Kröhnke, F. Synthesis 1976, 1. (b) Kröhnke, F. Angew. Chem. Int. Ed. 1963, 2, 380. 